Jakub Galuszka

\title{
Co-Production as a Driver of Urban Governance Transformation? The Case of the Oplan LIKAS Programme in Metro Manila, Philippines
}

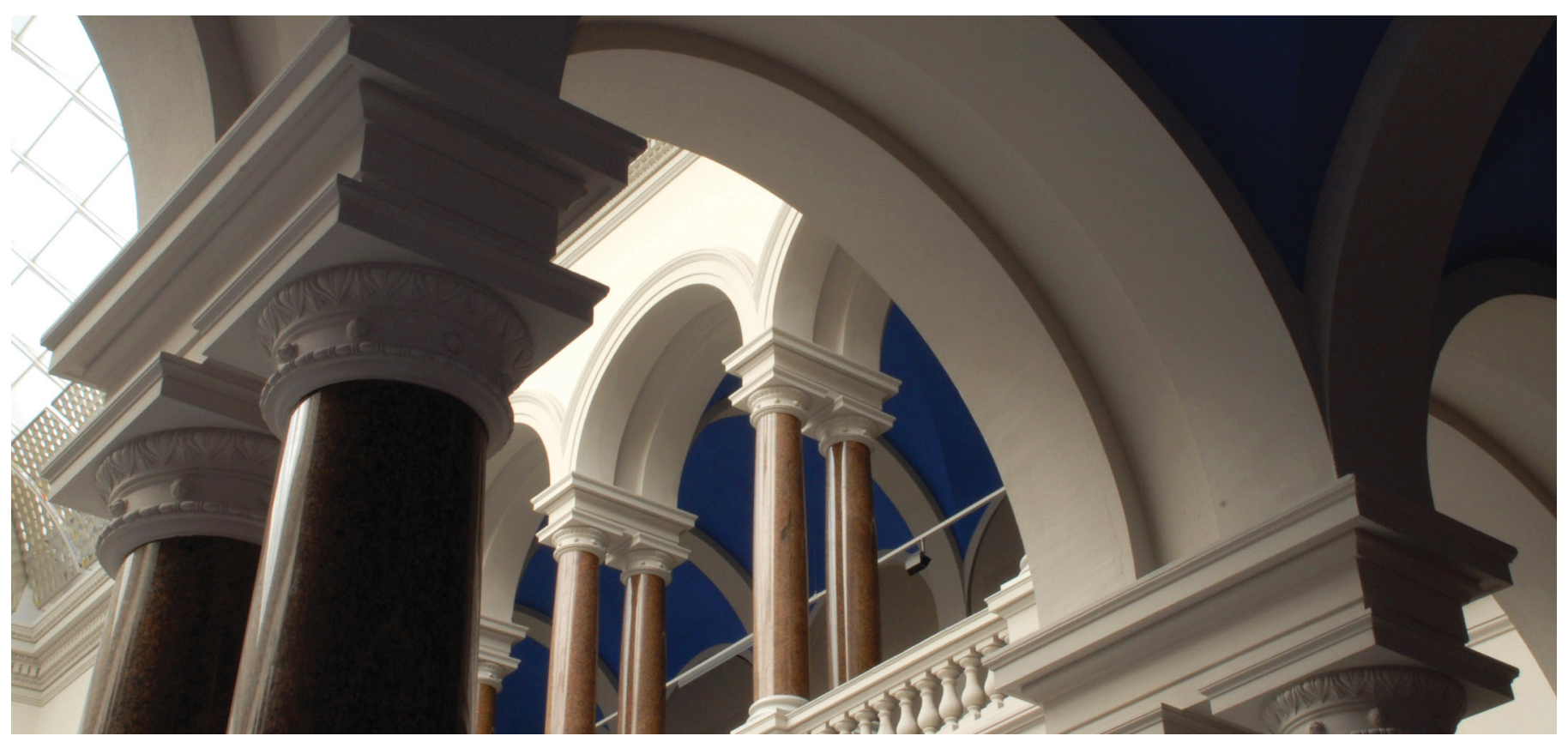

This article has been peer-reviewed, accepted and published in:

Galuszka, J. (2019). Co-Production as a Driver of Urban Governance Transformation? The Case of the Oplan LIKAS Programme in Metro Manila, Philippines. Planning Theory \& Practice, 20(3), 395-419. https://doi.org/10.1080/14649357.2019.1624811 
Co-Production as a Driver of Urban Governance Transformation?

The Case of the Oplan LIKAS Programme in Metro Manila, Philippines

\author{
Jakub Galuszka \\ Habitat Unit \\ Technical University of Berlin \\ jakub.galuszka@tu-berlin.de
}

Keywords: co-production, urban governance, housing, resettlement, Metro Manila, civil society, public sector

\title{
Introduction
}

Civil society activism has been considered one of the key shaping factors of contemporary cities (Castells, 1983), particularly in a context in which urbanisation pressures and exclusionary urban development practice have resulted in the emergence of massive poverty-ridden informal settlements. Although the span of these activities is vast and difficult to describe in a linear manner, one of the strains of the current debate captures these processes through the concept of social movement-initiated coproduction (Watson, 2014). The concept expands the traditional definitions that consider co-production mainly as a way to share resources and efforts by the representatives of different sectors engaged in a common project (Ostrom, 1996). These early conceptualisations identify co-production as a way to facilitate service delivery and as a mechanism to reorder the relationship between the public sector and the citizens. The current debate goes a step further by positioning co-production as a key factor that leads to a broader change in urban governance structures. Rather than only focusing on project-based matters, co-productive interventions are identified as having the potential for institutional restructuring and as a way to integrate various voices in the development process. This line of thought is amplified in the literature on urban transformation in the South (Watson, 2014), where co-production is considered an approach towards which urban poor groups consciously steer with the expectation of gaining wider control over the development process, accessing support from 
governments and bettering their position in the urban governance spectrum (Mitlin, 2008). In other words, these actors try to scale up the co-productive approach with the intention of achieving "far-reaching change" (Mitlin \& Bartlett, 2018, p. 363). Within a variety of often contradictory definitions (Brandsen \& Honingh, 2016) and a highly contextualised application of co-production (Environment \& Urbanization, 2018), this ambition of urban movements is described as one of the key features of the approach (Watson 2014; Mitlin \& Bartlett 2018). However, with the predominant focus on the description of influential factors of co-production rather than on their outcomes (Voorberg, Bekkers \& Tummers, 2015), as well as a focus on small-scale project-based case studies, reflection on the broader governance change process and outcomes, which co-production is supposed to instigate, is largely missing in the literature.

The aim of this article is to reflect on such a context and to analyse the process of governance change originated and steered by the urban poor sector as well as the outcomes of this process in terms of policy environment and practice. This is done through an analysis of the two-phased engagement of the Urban Poor Alliance (UP-ALL) with the urban governance of Metro Manila, and their role as co-producers of a major resettlement programme Oplan LIKAS (2011-2016) aiming at relocation and housing development for approximately 120,000 informal settler families (ISFs) living in floodprone areas. The first phase involves efforts to widen access to governance and is identified here as the 'scaling up' phase. The second, 'governance/implementation', phase involves the execution of the new position. Phase one includes the non-linear engagement of various organisations, which gradually advanced their position through decades of bottom-up work based, to a major degree, on principles of co-production. Building on these activities and the networking efforts of different groups, a major coalition of urban poor - the Urban Poor Alliance (UP-ALL) - was established in 2005 and progressively achieved a greater impact on policy making matters (Karaos \& Porio, 2005). The second phase analysed in this article commenced in 2010, when the UP-ALL signed a 10-point covenant with then presidential candidate Benigno Aquino III, who recognised the main housing policy demands of the alliance, including the landmark coproductive approach of the People's Plans, and its embedding in the Oplan LIKAS programme.

The article reviews the strategies of one of the major urban poor movements in Metro Manila which led them to this position, as well as the outcomes of attempts to 
scale up the co-productive approach of the People's Plans and in-city relocation as the policy of choice in low-income housing programmes in Metro Manila. As such, in theoretical terms, the article critically contributes to the current debate on coproduction of governance and reflects on the characteristics, prospects and limits of the approach beyond a project scale. By doing so it reflects on the broader premise of forming alternative modalities of engagement between the state and society. In other words, it asks to what extent the engagement, broadly defined as co-production, enables the formulation and embedding of inclusion mechanisms within the governance structures dominated by public sector and oriented towards the private sector's interests. In this sense, the article contributes to the debate on urban governance transformation through sharpening a theoretical understanding of co-production and identifying the conditions that such an approach would structure "planning and urban development processes in certain Global South contexts" (Watson, 2014, p. 63). Lastly, it tests the analytical approach (Galuszka, 2019) towards tracing the hidden dynamic underlying civil society-state engagement within the context of an exclusionary governance setting.

\section{Co-production - Primary Concepts}

The first studies of co-production were carried out in North America and the UK in the 1970s and were undertaken within the Economics and Public Management disciplines. Initially their main focus was on the reduction of service delivery costs and the increased efficiency that resulted from the sharing of responsibilities and resources by the public sector and citizens involved in the implementation of a common project. The aspect involving the creation of new types of relationships between the involved parties resonated more strongly in the following decades with the recognition that coproduction can serve as a relevant tool to reorder the relationship between urban dwellers and power holders. While some authors positioned this effect as an instrument enabling negotiations of regulations and norms by citizens (Bovaird, 2007), others identified it as an approach which provides an opening for more substantial change through the sharing of power and inputs in the service delivery process (Mitlin, 2008; Watson 2014) and policy-making (Whitaker, 1980). This line of thought resonated mainly in the literature on the urban transformation of the South, where informal 
urbanisation remained a dominant (and often the only available) housing mechanism for the urban poor. On the one hand, their engagement with service delivery was beneficial in that it helped communities to internally build strong and independent grassroots organisations (Mitlin, 2008) through fostering the need to federate and engage in collective action (Appadurai, 2001). On the other hand, activities like mapping (Watson, 2014), enumeration (Patel, Baptist \& d'Cruz, 2012), saving schemes (Mitlin, 2008; Archer, 2012) and microfinance (McFarlane, 2012a), translated to creation of own financial base and knowledge base which helps challenging existing power relations (Jasanoff, 2004) and, in effect, recalibrating the strategies of the authorities (Roy, 2009a). As a consequence, an enhancement of the negotiating potential of the communities and a strengthening of their position, vis-à-vis the state, was identified, including the opportunity to challenge the conventional modes of service delivery. Thanks to these features, the approach was applied as a deliberate strategy by the urban poor, with the aim of shifting the power structures and attaining wider responsibility for the planning and delivery of developmental goods (Boonyabancha \& Kerr, 2018). From the public sector point of view, this approach remained attractive because it allowed for increased service delivery, access to information and the design of better urban solutions. This is particularly relevant in the context of informal areas where some well-established developmental models might not work (Brown-Luthango \& Reyes, 2018). For instance, in the face of declining traditional registration mechanisms, community-led enumeration helped the public sector to understand the actual number of people living in informal settlements and to plan better interventions. At the same time, the clear benefits of the co-productive approach are not accepted by all public sector actors. Conflicting rationalities (Watson, 2003) and the general unwillingness of authorities to share power equally (Papeleras, Bagotlo \& Boonyabancha, 2012) mean that co-production can typically flourish in a context where the public sector is eager to experiment, where formal solutions have failed and where the long-term relationship and a track record of successful interventions incentivises them to work with the communities (Mitlin \& Satterthwaite, 2004). This worked in the favour of those communities who were able to establish long-term leadership, with the capacity to generate critical-mass support or to navigate intra-community dynamics towards the expected outcome (Patel, 2013; Galuszka, 2014) while not always being responsive to the needs of all community members (Rigon, 2014) and pre-determined 
by the existence of social capital (Voorberg et al., 2015). In more weakly organised communities this meant that a key role was played by NGOs acting as intermediaries between the authorities and the communities. Hence, in such contexts, the service delivery arrangement and cooperation format was also dependent on the wider positioning of an NGO within the local political and development aid structures and so on (Banks, Hulme \& Edwards, 2015). Although, subjected to those complex community and political dynamics (Pieterse, 2008), as pointed out by Watson (2014), coproduction made it possible to counteract some of the main disadvantages of more established forms of participatory development, including the risk of co-option of independent movements and issues related to the creation of artificial representative structures (Cooke \& Kothari, 2001; Cornwall, 2004; Swyngedouw 2005; Miraftab, 2009; Lemansky, 2017). Apart from the scaling up approach and the 'showing by doing' strategy, this was achieved by enabling the mainstreaming of approaches of civil societies which did not fit into existing regulatory frameworks. Furthermore, it allowed control of the development process to move beyond mere consultation of ready-made solutions and enabled participation in a diversity of activities such as co-financing, comanagement, co-implementation etc. (Watson, 2014; Bovaird, 2007). This was often forged through a more conflict-ridden process as opposed to a classical participatory governance setting (Albrechts, 2013; Galuszka, 2019).

\section{Co-production of Governance}

Given its transformative potential, co-production has been increasingly discussed as a tool for stimulating transitions in the way cities are governed. The creation of multi-stakeholder spaces through a co-productive approach is seen as a means to foster a new policy formulation environment (Frantzeskaki \& Rok, 2018), bringing a change in the way decisions are made (Wyborn, 2015). In spite of its deeply decentralised character, particularly in the context of precarious settlements, the approach resonated beyond small-scale neighbourhood or district level scenarios. Wide international recognition of the power and influence of networks such as Slum/Shack Dwellers International (SDI) and the Asian Coalition of Housing Rights (ACHR) (Herrle, Ley \& Fokdal, 2015; Watson 2014; Bradlow, 2015a), which grew from the bottom-up work of regional affiliates, reinforced the ambition to scale up and mainstream co- 
productive solutions on a wider city scale (Mitlin \& Bartlett, 2018). An increasing interest in the literature dealing with the ways in which the informal sector affects urban governance (Sermiento \& Tilly, 2018) translated into an analysis of the impacts on governance of co-production in the South. In the early 2000s, Joshi and Moore (2004) identified logistical as well as governance drivers of the approach, with the latter being primarily directed at addressing governance capacities of the state. A range of authors (Ackerman, 2004; Brandsen \& Pestoff, 2006; Bovaird, 2007) reinforced the distinction between different levels of co-production, while underscoring the potential impact of citizens on policy making and governance, for instance through comanagement or co-governance. However, most of these interpretations, mainly originating from the Northern context, supported the view that the process needs to be driven by a public sector proponent and should include regulatory mechanisms such as institutionalisation and fixed frameworks ensuring sustainability of the arrangement. The applicability of these assumptions was questioned in the case of the governance transformation, particularly in the context of the South. In particular, the positioning of the co-productive process as external to community groups or as an invited space of participation (Cornwall, 2004) was identified as bearing a similar risk as the aforementioned participatory schemes (Richardson et al., 2018) or as a mechanism having limited impact on the policy change process (Galuszka, 2019). As previously mentioned, the creation of openings for communities to be included in governance choices rather than only in co-implementation remains crucial here if the people are not to be relegated to a role in mere service delivery (Mitlin \& Bartlett, 2018). This risk remains real as governments may find it both attractive and practical to "offload service delivery to NGOs and community groups or convince local residents to donate volunteer labor or materials" (Ackerman, 2012, p. 102). Access to governance, except with regard to the scaling up of the solutions of urban groups and movements (Mitlin \& Bartlett 2018), has the benefit of increasing the accountability of the public sector (Ackerman, 2004) and enabling the self-positioning of citizens vis-à-vis the state. Yet, the way in which this access is achieved appears to be equally crucial in the context of urban change in the South. For instance, some initial reports suggest that co-production can have equally empowering and disempowering effects (Moretto et al., 2018) and can be contested by authorities when attempting to scale up (see Chitekwe-Biti, 2018). This risk resonates at higher governance levels. In fact, even when co-production is 
embedded in governance systems, but not steered by grassroots, as in the case of the land delivery system in Ghana, the arrangement may have exclusionary impacts on the general population (Akaateba, Huang \& Adumpo, 2018). For these reasons the understanding of co-production adapted in this article builds on the central assumption that the organised communities, rather than the public sector, need to drive the process (Boonyabancha \& Kerr, 2018) and that their involvement extends beyond one single phase of a project. That involvement should impact on the design, management and execution of the process. Consequently, the analysed approach of this article is defined as co-production of governance which is an "open-ended process that enables the urban poor to continuously affect, review and update policies within or outside of formally recognised bodies" (Galuszka, 2019, p. 150), while bearing in mind, that the impact of organised groups of citizens on governance should "mirror their own protocols and safeguard principles of flexibility and collective action" (Galuszka, 2019, p. 150). The methodological considerations for inquiring into the nature of such a process are described in the following section.

\section{Analytical Framework and Methods}

The first major aim of this article is to trace the process of governance transformation instigated by the grassroots through a co-productive approach with the intention of scaling it up as the main solution for housing the poor in Metro Manila. Two phases of the engagement are identified and analysed: the first is the scaling up phase, the second is the governance/implementation phase. The first phase is described in terms of the variety of approaches that led to governance change. Its outcomes are evaluated based on the capacity to attain the goals set out by the UP-ALL and the achievement of new positioning within the housing governance structures in Metro Manila. The analysis of the second phase and its outcomes, as previously stated, is conducted beyond a projectlevel context. Consequently, rather than looking at specific projects realised within Oplan LIKAS (which have taken very different trajectories based on specific location, involved intermediaries, etc.), the article is concerned with the overall effects on governance and the actual integration of the co-productive approach of the People's Plans and the governance factors which shaped the implementation of the programme. 
The second major aim of the article is to deepen the understanding of the process of co-production in the context of the South. I argue that a discussion of the local specifics of the governance process is necessary to grasp the reasons for the achievements of the UP-ALL in the scaling up phase and the failures of the arrangement in the governance/implementation phase. That is, this study goes beyond the assumptions underpinning the successes of co-production and its governance effects in the European and North American contexts and seeks to understand relations, factors of change and outcomes of governance process transformation in a complex governance system that is decentralised but dependent on political leaders, and that incentivises bottom-up work but also undermines and co-opts it (Shatkin, 2007; Hutchison, 2007).

In particular, it reflects on three key issues that are considered to distinguish the co-productive process in different settings and intellectual traditions and are proposed as a guideline for analysing the governance change process in the South (Galuszka, 2019). These are:

- Positioning of the institutionalisation of a participatory space as a precondition for its sustainability (Ackerman, 2004; Joshi \& Moore, 2004) versus the importance of maintaining a degree of independence from this space by civil society (Galuszka, 2019). Specifically, this issue focuses on understanding to what degree the civil society can preserve its approaches and get them inscribed into law, although these approaches are usually based on a completely different developmental or implementation logic, and exist because legal or regulatory frameworks fail (Watson, 2014).

- How cooperation and conflict are treated and what resources are used to reorder power relations between citizens and the state. This includes the consideration that a combination of the two is typical in the South and is usually required for civil society to advance with its agenda (Watson, 2014; Bradlow, 2015b; Miltin 2018), particularly in the scaling up phase. Simultaneously, this issue poses the question as to whether the declared depoliticised nature of some sectorial-oriented civil society movements (Dikeç \& Swyngedouw, 2017) and their declared non-conflict orientation, suffice to affect urban governance on a broader metro scale.

- Two intertwined, but often exclusionary, objectives of civil society activism: control over the development process and redistribution of resources (Galuszka, 2019). That is, this issue reflects on the notion of co-production as a manifestation of the neo-liberal tendency to push service delivery responsibility away from the public sector (Miraftab, 
2004) and on the assumption that the redistribution of resources may be linked to an increase in the state's control over the development process (Huchzermeyer, 2003). I ask whether the civil society can merge these two objectives and whether co-produced governance can help the civil society to achieve it.

The proposed analytical device can reflect on the hidden dynamic underlying the civil society - state partnership in the context of an exclusionary governance setting. While many co-productive approaches across the global South are documented through the prism of lower project costs or wider service delivery, these measures may, in fact, not be the dominant factors for the inclusion or exclusion of specific solutions or groups from a particular governance setting. The review of the contradictory nature of the coproductive process reaches to those 'non-technocratic' motivators of urban governance change, and aims at deepening the understanding of the governance processes in the South.

This article draws on data collected during fieldwork conducted in Metro Manila between November 2017 and March 2018, including interviews, site visits and the analysis of quantitative and spatial data sourced from the local shelter agencies and civil society organisations. Overall, 37 in-depth, semi-structured interviews were conducted (including 7 in a group setting). The selection criteria for the interviews included engagement in the formulation and/or implementation of the Oplan LIKAS. Additionally, it involved screening for representatives of different sectors and organisations. These included leaders of the UP-ALL involved in the establishment and implementation of the Oplan LIKAS as well as partner community organisations and NGOs $^{1}$. Additionally, interviews were undertaken with a parallel urban poor bloc organised around the Institute for Popular Democracy/Kilos Maralita which benefited from a big proportion of the funding delivered for in-city resettlement.

As such, the research included interviews with the two main urban poor blocs in Metro Manila which engaged in co-productive action: the UP-ALL - largely composed of apolitical or broadly pro-democratic (liberal) groups and Kilos Maralita - linked to the left political block. The remaining major network - Kadamay - in principle rejects the co-productive approach and orientates itself towards more radical measures including

\footnotetext{
${ }^{1}$ Such as: TRICOR members: Community Organisers Multiversity, Urban Poor Associates; KOSMA (Coalition of People's Organizations in Manila); CMP Congress members (former representatives of the Foundation for the Development of the Urban Poor), Homeless People's Federation Philippines, DAMPA (Damayan ng Maralitang Pilipinong Api), TAO Pilipinas, Partnership of Philippine Support Service Agencies.
} 
housing occupation and land invasions ${ }^{2}$. Interviews were also conducted with former and current representatives of the public sector holding managerial and senior bureaucratic positions in the main implementing agencies: the Department of Interior and Local Government (DILG), the Social Finance Housing Corporation (SHFC), the National Housing Authority (NHA), the Presidential Commission for the Urban Poor, as well as representatives of the Local Government Units, mainly at the level of Local Housing Boards. Interviews were also conducted with community members on the 'implementing/receiving' end in three communities where resettlement projects were either finalised or near completion, as well as in two communities in the pre-relocation stage.

\section{Inclusive Foundations and Exclusive Practices in Housing Governance in Metro Manila}

The urban poor movement has been intensively organised in Metro Manila since the 1970s. It was originally composed of very diverse communities that were brought together by a unifying anti-eviction agenda and opposition to the repressive Marcos regime. During this period the groups had relatively few possibilities for engaging in governance matters through official channels and tried to exercise their influence through politicised and confrontational means (Shatkin, 2002). The change in political rule in the Philippines in 1986 and the adoption of in-depth decentralisation reforms significantly altered the nature of the movement and the scope of its activities (Karaos, 2006). Its function at that time was to benefit from enabling laws, particularly the Local Government Code of 1991 and the Urban and Development Housing Act (UDHA) of 1992, which devolved many of the centralised powers to the local government units. The essence of these new laws was to involve the representatives of people's organisations, community groups and NGOs in the development process by changing their position from beneficiaries to key stakeholders in the settlement upgrading process. These aims were manifested in the National Shelter Programme, which was linked to the decentralisation of housing production and legitimised the state position as an enabler of housing rather than its provider (Ballesteros, 2002). Under these

\footnotetext{
2 This article employs the term 'urban poor movement/bloc' to refer to the two major fractions which support engagement in co-productive action and refrain from radical contestation measures.
} 
conditions, numerous urban poor coalitions flourished and engaged actively in local urban development matters.

However, these progressive foundations were not smoothly translated into inclusive development practice, with many of the local elites from both the government and the private sector acting as a stumbling block in the implementation of pro-poor policies (Shatkin, 2007). The roots of this dichotomy, which is also linked to practical reasons such as competition for land and profit, can be attributed to the "ideological currents operating through local real-estate markets" (Garrido, 2013, p. 167). The preference of elite consumers for exclusive spaces and the related routine of planning practice remained in contrast to such policies as securing in-city land for low-income populations and the development of social housing. In practice, this kind of "off-thescene" resistance of power holders was reinforced by the merging of political and economic elites (Kleibert, 2018) and manifested itself in a variety of ways, ranging from negligent implementation of progressive policies to the difficulty of transforming public institutions (Constantino-David, 2004). Likewise, even though innovative participatory mechanisms had been established, the outputs of these spaces still largely depended on the willingness of top decision makers. In her analysis of networked governance practices in two cities in Metro Manila, Porio (2012) documents that decentralisation may have transformed the traditional bureaucratic structures but at the same time was used by mayors to reinforce their control over the development process. The range of strategies involved not only the creation of alliances and networks supportive of their agenda, but also actions that are conventionally considered to support co-production (Joshie \& Moore, 2004), namely the institutionalisation of regulatory frameworks and practices. This finding is confirmed from the point of view of community-based organisations. When building relationships with a multitude of 'formal' actors, including donors and government officials, these actors tend to attempt to maintain control of the development process rather than share it equally (Papeleras et al., 2012).

The issue also relates to the aspect of financing. The openings offered by the political transformation did not result in increased access to state resources and "protection as a justifiable right" but rather in the creation of spaces for bargaining for access to services and resources (Hutchison, 2007; Shatkin, 2002). As much as decentralisation has resulted in the emergence of an active civil society to date, the budget for housing has remained marginal for decades. In the years 2000-2007, the 
Philippines invested the least money on average on low-income housing compared with other South-East Asian countries (Habito, 2009). Unsurprisingly, the issue of substandard housing conditions is nowhere near being resolved. Out of the approximately 13 million people living in Metro Manila, between 1.3 and 3 million are estimated to live in informal settlements (World Bank, 2016).

This paradoxical positioning of the urban poor and inclusive policies has been reflected in the local, public sector-led housing and tenure-focused programmes. A study of the overall number of assisted informal settler families from Metro Manila in the last decade reveals that the progressive solutions based on co-production principles benefited only a small number of people in comparison with top-down resettlement schemes delivered by developers. For example, the Community Mortgage Program, which positions communities in the centre of the land formalisation process, benefited 26,480 households between 2005 and 2011. From 2005 to 2010, the resettlement programme delivered 107,079 housing units (Galuszka, 2014). Consequently, the overwhelming majority of the low-income housing produced in Metro Manila and surrounding area is linked to the most contested format of development, namely, offcity relocation, which means people receive "little boxes on tiny resettlement plots in a vast grid development designed by $\mathrm{NHA}^{3}$ engineers and built expensively by contractor" (Papeleras, et al., 2012, p. 474).

\section{The Scaling Up Phase: the UP-ALL and the 10-Point Covenant}

Given the limited reach of innovative solutions and the perpetual housing shortage, efforts to find solutions towards a wider inclusion of the urban poor in the housing sector continued. In response to the forced relocations happening around Metro Manila (Mabilin, 2014), many of these activities were in the past steered by antieviction groups. Even before 1986, there were strong movements that utilised networking mechanisms with the intent to challenge official policies. One of the largest networks of this time, the Zone One Tondo Organisation (and its umbrella organisation Ungayan), emerged as a relatively strong grouping utilising politicised and confrontational tactics and organised around an anti-eviction agenda. The group

\footnotetext{
${ }^{3}$ NHA: The National Housing Authority is the main housing agency mandated to provide housing for relocated families in the Philippines.
} 
succeeded in negotiating with the authorities and took part in the World Banksupported upgrading project in the Tondo district of Manila, the first major project promoting self-help and community engagement in informal settlement upgrading. The outreach of these early organisational efforts was short-lived; in the early 1980s CBOs and NGOs started falling out with each other over political stances (Shatkin, 2002). While decentralisation reform, which continued beyond 1986, supported the growth of various community-based organisations, it also resulted in the demobilisation of the urban poor movement (Shatkin, 2002). During the following decades, even the groups who were most successful in negotiating with the government did not emerge as a wider movement advocating land reform. This consequence was linked to the specifics of the governance structures, which enabled the urban poor to bargain for access to services while subjecting themselves to the patronage of powerful figures and to the political process (Hutchison, 2007). One example of this is the arbitrary instrument of the presidential proclamation, which gives a president the right to allocate land to a specific group by virtue of an executive order. Although it supported the development of many informal settlements and helped to stop forced evictions, it was also used to dismantle a wider coalition focused on comprehensive urban land reform. It shifted the focus of grassroots organisations to the immediate needs of the people in a territorially circumscribed manner (Karaos, 2006).

Aside from these groupings that primarily centred on advocacy, court action or community work in a specific location, numerous community-based organisations focused on co-production within or outside of the official governmental schemes. A number of governmental programmes, such as the Community Mortgage Program or the incremental modality of the Resettlement Program, incentivised this approach and mobilised a large number of communities across Metro Manila to engage in coproduction. The approach was also steered outside of the established regulatory frameworks of the key shelter agencies. On a small scale, this engagement involved, for example, making local plans and facilitating the incremental construction of housing by people with materials and the technical guidance of local government units (see BASECO case where multiple organisations engaged in co-productive schemes towards settlement upgrading) (Galuszka, 2014). On a large scale, federations engaged in independent initiatives which included various power-building activities through the generation of their own resources, knowledge and planning routine. One example of a 
people's organisation is the Homeless People's Federation Philippines (HPFPH), which was formed in 1998. In its early phase, this federation developed savings schemes and networked the urban poor in Metro Manila (Yu \& Karaos, 2004), and later moved on to mapping activities. The success of this approach was documented in 2015 in Muntinlupa City where the informal settlement mapping was carried out. This case was supported by the authorities and became a source of information for the development of local upgrading and resettlement strategies. Simultaneously, engagement in regional activities through large international networks (Karaos \& Porio, 2015) enabled the group to strengthen its position as a reliable partner of both development aid agencies and academics and therefore able to access funding opportunities.

It can be argued that the combination of movements utilising different strategies was what provided the opportunity for a significant reordering of the existing civil societypublic sector relationship. The major stepping stone was the establishment in 2005 of the nationwide umbrella organisation UP-ALL. Its launch brought together 120 people's organisation leaders, representing about 600 organisations from around the country (Karaos \& Porio, 2015). The UP-ALL also involved NGO representatives, including the 'Partnership of Philippine Support Service Agencies' network, which had actively supported the community-based organisations in Metro Manila, since 1988. Many of these organisations specialised in different issues, such as networking and coproduction, and some included in their portfolio protest means and court action ${ }^{4}$. Building on their different capacities, the founding members agreed on a 14-point agenda that steered the advocacy efforts of the alliance. Overall, although part of the group incorporated activities rarely considered to be part of a co-productive approach, such as court action, in principal the groups agreed to a non-violent orientation and practised building synergies with government through engaging in co-productive solutions on the ground. Similarly, most of the advocacy work, or court action, was directed towards the increased responsibility of the people for service delivery and programme design, thereby strengthening their position as co-producers of housing.

As reported by Karaos and Porio (2015), in the years following its establishment, the UP-ALL achieved significant successes mainly in terms of reinforcing the Social

\footnotetext{
${ }^{4}$ For example, the aforementioned HPFPH follows the logic of the SDI and refrains from engaging in rallies and manifestations. Another strong bloc in the UP-ALL, the groups under TRICOR remains active in this field, while in parallel it is engaged in various on-the-ground co-productive projects with the public sector.
} 
Finance Housing Corporation (the agency responsible for delivering the Community Mortgage Program) and defining the rules and regulations surrounding the titling and upgrading of informal settlements on government-owned lands.

However, the landmark opportunity to further the agenda of the alliance arrived in the run-up to the presidential elections in 2010, when the civil society explored the openness of the candidates to their agenda. During this time, "the urban poor movement made a deal with then-candidate Aquino, so the liberal party (...) wrote an agreement with the Urban Poor Alliance that there shall be shift of the strategy from off-city to incity relocation" (civil society, 27.12.2018)5 ${ }^{5}$. The massive alliance could not be ignored by the politicians because it represented a significant voting base, which could make itself visible through rallies and 'street-level' support for a specific candidate. Consequently, during the final run-up to the elections, Aquino entered into an agreement with the UP-ALL, namely a 10-point covenant on the demands of the urban poor sector.

\section{Establishment of the Oplan LIKAS}

Although the signing of the 10-point covenant was the essential driver for the establishment of the Oplan LIKAS programme, the urban poor were effectively able to steer their activities through several external factors. Most importantly, the engagement was also motivated by a Supreme Court mandamus from the year 2008 that ordered the clean-up of Manila Bay and waterways in urban areas within a three-metre zone. The order indicated the relocation of a large number of informal settlers living along waterways. Around the same time, in 2009, the Philippines was struck by a number of devastating typhoons, including Typhoon Ondoy. Along with the advocacy bestowed by the 10-point covenant, the civil society "groups realized that as a strategy we can use what happened during Ondoy to better convince the government. So then we constructed the lobbying statement: government you spent now, before the disaster happens" (civil society/public sector, 24-11-2017) and "for government that was logical move, logical thinking to transfer these people away from this waterways" (civil society,

\footnotetext{
${ }^{5}$ The interviewees are referred to based on the sectors they were involved in: ether public sector in general (including government or key shelter agency) or civil society (including People's Organisations) as well as civil society/ public sector for those who were engaged in both sectors at various stages of the Oplan LIKAS programme.
} 
08-12-2017a). The civil society effectively gained more leverage to push for its own approach, and the mandamus, which could have posed a major threat of uncontrolled evictions, became an opportunity for better housing. Consequently, at the beginning of President Aquino's term, the Oplan LIKAS programme began to be formulated. The process involved a series of convergence meetings and the formulation of the Informal Settler Families National Technical Working Group, which consisted of representatives of CSOs, local authorities and 13 public sector agencies involved in the programme in various capacities. The work also benefited from the technical assistance of the World Bank.

Although the realisation of the 10-point covenant was difficult from the start (Gerald, 2011), its process and the resources devoted to the programme suggests that it went beyond a classical clientelist relationship and, as Hutchison (2007) puts it, the disallowed political participation of the urban poor. Therefore, it enabled true coproduction of policy solutions and access to governance, which contrasts with some participatory spaces established by power holders in Metro Manila only to reinforce their political influence (Porio, 2012). Similarly, in contrast to the logic of the populist appeal and the performance of sincerity (Garrido, 2017), the deal between Aquino and the UP-ALL created a channel for the realisation of some of the key demands of the civil society. This achievement can be captured within the three dimensions of the Oplan LIKAS programme:

\section{Financial Base}

In accordance with points 4 (housing budget) and 8 (post-Ondoy rehabilitation programme) of the covenant, the programme responded to the unrelenting advocacy of the urban poor for an increase in the budget for low-income housing. In November 2011, P50 billion (approximately US\$ 1.15 billion) was allocated for the period 20112016 to house 104,000 ISFs (later increased to around 120,000 families) (World Bank, 2016). The reserved budget was the most significant financial input into the social housing sector in the last decade (HUDCC, 2017) to be utilised by settlers living in Metro Manila regardless of their affiliation with a specific political bloc. 


\section{Integration of the Urban Poor's Advocacy Points into the Planning of the Programme (in-city relocation and People's Plans)}

From the start, the civil society was involved in the formulation of the programme through the work of the ISF-National Technical Working Group. The initial debates and documents shaped by the Working Group supported two key agenda points of the civil society: the in-city relocation and the adaptation of the People's Plans. The former represented the continuous struggle of urban poor communities to avoid relocation to distant off-city locations, which typically resulted in unemployment and related issues. The latter legitimised the co-production of multi-storey housing between the state and the urban poor. Specifically, it assumed the alternative shelter planning approach that involves ISF community members in the process of creating, drafting and generating their plan for housing and community development. From forming their community associations, building their capacities, designing their housing and community, as well as negotiating with landowners and developers, to managing and maintaining their own housing and community (Patiño, 2016, p. 29).

Overall the approach was reflected in relevant documentation such as the Memorandum Circular resulting from the works of ISF - National Technical Working Group as well as in a number of new programmes established at a later stage, including: High Density Housing of the SHFC and the Micro-Medium-Rise Building modality of the DILG. This approach is directly related to point 10 (participation and stakeholdership) and indirectly to point 2 (provide support for area upgrading and in-city resettlement) of the covenant.

\section{Embedding the Civil Society into Key Shelter Agencies}

The civil society sector influenced the selection of the staff responsible for the implementation of the programme and its institutional setup. Consequently, the programme was settled within the DILG. As noted by one of the civil society leaders: "Most of our networks were there, they were hired because we really pushed" and "during that time we had a very good Secretary of Local Government, Jessie Robredo" (civil society, 08.12.2017b) who previously served as the mayor of Naga City and was known for applying participatory governance measures. Similarly, in accordance with the preferences of the CSOs, the programme was embedded in the Social Housing 
Finance Corporation, which was chaired by the representative of the non-governmental sector, Ana Oliveros. Consequently, two out of the three main agencies (Figure 1), which were about to receive money for the implementation of the programme, were truly influenced by the CSOs. Only the NHA, traditionally responsible for the resettlement programme, was beyond this influence. This indicated the partial delivery of point 9 of the covenant (the appointments).

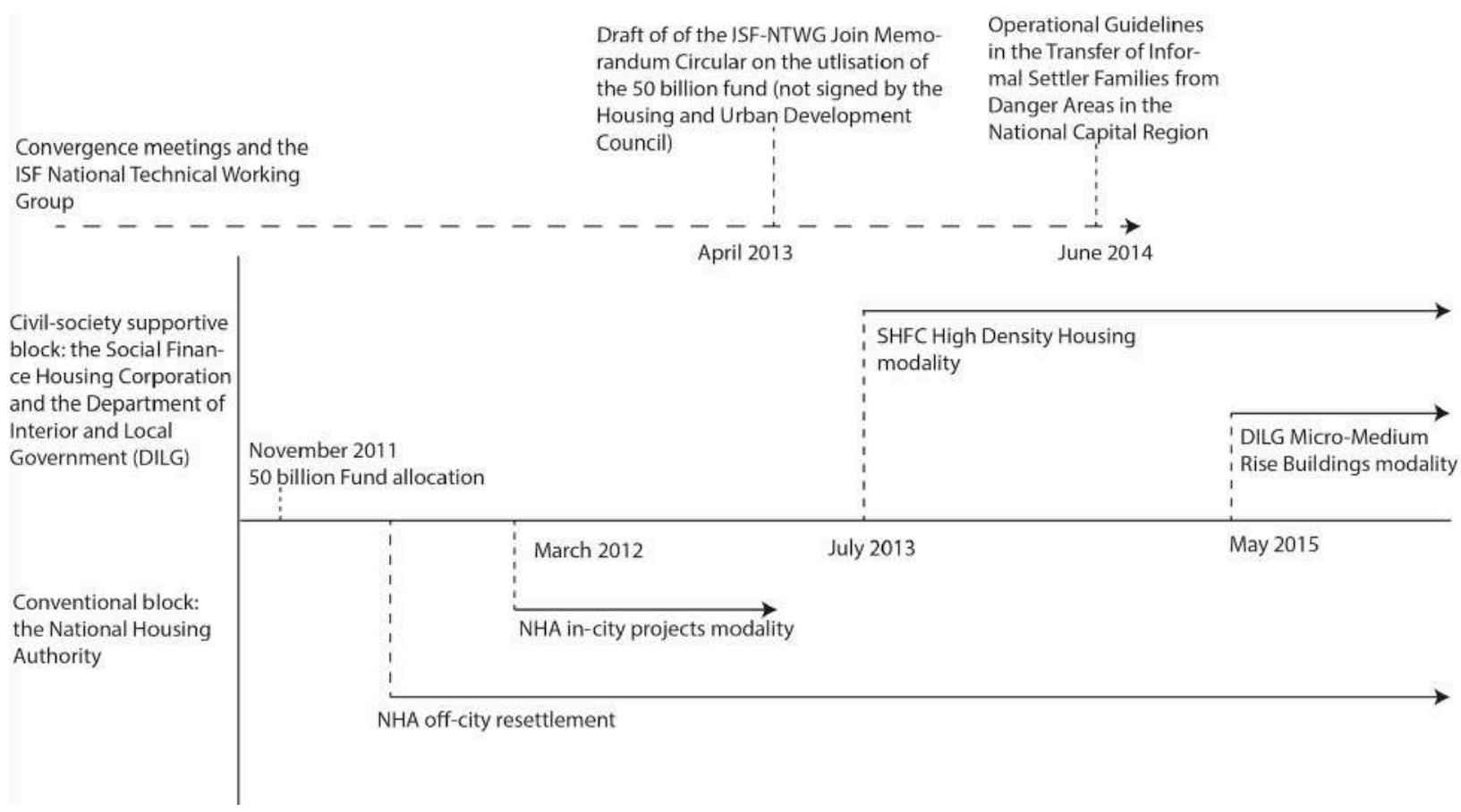

Figure 1. Simplified time frame of the Oplan LIKAS programme.

\section{Governance/Implementation Phase: Top-Bureaucratic and Community-Level Competition Over the Programme's Approach}

With a number of tangible and unprecedented achievements at hand, Oplan LIKAS was “a golden opportunity, was supposed to be a golden opportunity to push for people's driven shelter because we had the funds" (civil society/public sector, 01.12.2017). However, unlike in the empowerment phase in which CSOs acted as an extraneous power, the programme implementation period posed a set of completely new challenges that signalled the volatility of its previous achievements. Two clear blocs 
started to emerge in the initial stage of the programme. The first one, supportive of the approaches of the urban poor, centred on two main implementing agencies: the DILG and the SHFC. The second one, in favour of classical top-down housing measures, was centred on the NHA. The final figures of the programme (Table 1) showed that only around $25 \%$ of the fund went to the progressive bloc. Although the scale of this shift became obvious only at the end of the programme, its initial years already suggested that the civil society agenda was becoming undermined, specifically when the involved stakeholders realised that the first P10 billion would be allocated exclusively to the NHA because "the release of 10 million to NHA is very, very inconsistent with the spirit or intention of (...) the Joint Memorandum Circular because the NHA is an agency that builds relocation sites mostly off-city, on distant relocation sites" (civil society, 27-122017). This poses the question: How was such an obvious diversion from the essence of the initial agreements possible so early in the process?

Table 1. Breakdown of the 50 billion fund, source: DILG $(2017,2018)$

\begin{tabular}{|c|c|c|c|c|}
\hline AGENCY & $\begin{array}{l}\text { TARGET UNITS/ } \\
\text { UTILISATION OF THE } \\
\text { FUND }\end{array}$ & $\begin{array}{l}\text { NUMBER OF } \\
\text { HOUSING UNITS } \\
\text { DELIVERED }\end{array}$ & $\begin{array}{l}\text { BREAKDOWN } \\
\text { OF FUNDING } \\
\text { (in PhP) }\end{array}$ & $\%$ \\
\hline $\begin{array}{l}\text { National } \\
\text { Housing } \\
\text { Authority }\end{array}$ & Target: 101,210 & $\begin{array}{l}\text { Completed: } 85,053 \\
\text { Occupied: } 63,022 \\
\text { Off-city: } 75,215 \\
\text { In-city: } 9,838\end{array}$ & 32,21 billion & $64,42 \%$ \\
\hline $\begin{array}{l}\text { Social Housing } \\
\text { Finance } \\
\text { Corporation }\end{array}$ & Target: $19,658^{6}$ & $\begin{array}{l}\text { Completed: } 3729 \\
\text { Occupied: } 730 \\
\text { Off-city: } 6 \text { projects } \\
\text { Near city: } 9 \text { project } \\
\text { In-city: } 12 \text { projects }\end{array}$ & 9,484 billion & $18,97 \%$ \\
\hline
\end{tabular}

\footnotetext{
${ }^{6}$ The number of target units has changed during the Oplan LIKAS process. The numbers indicated here are based on the data of the DILG (2017 and 2018). The overall target of the NHA and SHFC is set here at 120868 units.
} 


\begin{tabular}{|c|c|c|c|c|}
\hline $\begin{array}{l}\text { Department of } \\
\text { Interior and } \\
\text { Local } \\
\text { Government }\end{array}$ & $\begin{array}{l}\text {-Fund allocation of P1,05 billion } \\
\text { to LGUs for development of } \\
2248 \text { housing units within } \\
\text { People's Plans driven projects. } \\
\text { Part of the funding to be utilised } \\
\text { by the SHFC for the delivery of } \\
718 \text { housing units. } \\
\text {-Provision of interim shelter } \\
\text { fund P } 180,000 \text { for } 52734 \text { ISFs. }\end{array}$ & $\begin{array}{l}\text { Target: } 2248 \\
\text { Accomplished units: } 434 \\
\text { Off-city: } 1 \text { project } \\
\text { In-city: } 7 \text { projects }\end{array}$ & 2,489 billion & $4,98 \%$ \\
\hline $\begin{array}{l}\text { Department of } \\
\text { Social Welfare } \\
\text { and } \\
\text { Development }\end{array}$ & $\begin{array}{l}\text { One project: Provision of } \\
\text { housing to ISFs of Estero de } \\
\text { San Miguel }\end{array}$ & In city: 1 project & 531 million & $1,06 \%$ \\
\hline $\begin{array}{l}\text { Presidential } \\
\text { Commission } \\
\text { for the Urban } \\
\text { Poor }\end{array}$ & Social preparation activities & - & 40 million & $0,08 \%$ \\
\hline Unallocated & - & - & 5,243 billion & $10,49 \%$ \\
\hline
\end{tabular}

The first major issue lay within the implementation and institutional logic of the programme that countered its progressive spirit. On one hand, the civil society agenda, including in-city resettlement and the People's Plans, was positioned as a set of guiding principles for the implementation of the programme. On the other hand, Oplan LIKAS was a resettlement programme, and the legal framework, existing mandates of the key shelter agencies and professional routine positioned the NHA as their 'natural' proponent. The duality of the approaches translated into an intense competition among the implementing agencies, and epitomises Lefebvre's (1974) argument that space is the stake of politics. This competition resonated along different levels of governance. At the level of top decision makers, it involved formal and informal lobbying in favour of their preferred approaches and, unsurprisingly, was motivated by political and economic interests. The issue was manifested in the works of the National Technical Working Group on the ISFs, the outputs of which were contested by some public agencies. The draft documentation reinforcing the in-city resettlement and People's 
Plans was approved by the majority of housing agencies and the civil society in 2013. Nevertheless, the last signature on the document was signed towards the end of the programme. "The HUDCC (Housing and Urban Development Council) was the last one to sign this and as a condition to sign they put provision here that the money given to them ${ }^{7}$ prior to signing of Circular will not be covered by the circular" (government, 1902-2018). That is, a large portion of the money used for large, distant, off-city relocation sites in the first years of the programme by the NHA could not be questioned as a misuse of the fund. One of the motivating factors for the HUDCC to challenge the signing of the programme's documentation was the political positioning of the agency. At the time, it was chaired by the leader of the political opposition, vice president Jejomar Binay, who was the running mate of an unsuccessful candidate in the 2010 presidential elections, and one of the civil society representatives expressed the following view: "I think that the HUDCC as chaired by Binay, vice-president (...) to the National Technical Working Group is an unnecessary aberration from the president, for they could have implemented the whole thing on their own" (civil society, 27-12-2017). In fact, although in 2010 vice-president Binay publicly urged for a change to the existing resettlement modalities, saying, "There have been numerous complaints on the manner by which government is handling the resettlement of informal settlers. It has proportionately increased the concern of stakeholders over the capacity of NHA and other housing agencies to effectively implement plans and programs of resettlement" (HUDCC, 2010), the refusal to sign the Joint Memorandum Circular in 2013 was a clear statement against the transformation of the resettlement approach.

The second issue is that the support given to off-city resettlement was related to the practical need of the NHA to fulfil pre-existing contracts with their partner developers, even though the format and location of the housing sharply contradicted the principles of the in-city relocation and People's Plans. The financial mechanism, which, conveniently for the NHA, assumed the disbursement of money in yearly 10 million instalments, further supported the agency in promoting its solutions. Predicting how challenging cooperation with the NHA would be, the CSOs were already pushing to embed the programme into the DILG prior to 2011. However, this move was insufficient, and the resistance of the NHA and the HUDCC counterbalanced the

\footnotetext{
7 National Housing Authority
} 
influence of CSOs on the other implementing agencies. This suggests that direct access to governance space, in which civil society could, formally or informally, try to affect the planning process, did not automatically mean that the civil society had the capacity to navigate the new bureaucratic struggles (Galuszka, 2019) guided by a completely different set of developmental logic (Watson, 2003).

Simultaneously, the competition between the progressive and the conventional approaches trickled down to ground level, where local groups began to be approached by external mobilizers who tried to obtain their support for one of the modalities of the programme. Knowing that a majority of the funding would be initially consumed by the NHA, some urban poor groups tried to approach the agency and negotiate for an in-city option, an effort that turned out to be unsuccessful at that stage. Consequently, the civil society continued its advocacy to position the SHFC as the recipient of a portion of the P50 billion fund. This goal was achieved only in 2013 when the High Density Housing programme was established (Figure 1). This experience revealed a broad trend of communities being dragged between People's Plans and off-city relocations. The civil society attributed the large number of communities convinced to move to off-city sites as an effect of the conscious campaigning of the NHA and some of the local governments against the People's Plans. These plans were presented as being long and uncertain, which narrowed down to a message that "if you don't take NHA housing now you will be demolished and evicted anyway and you might find yourself without a housing unit assigned to yourself" (civil society, 27-12-2017). Ironically, in the public domain, the rushed relocation to off-city sites was also backed up by the disaster risk reduction logic, which made local governments liable for cleaning a three-metre area along the waterways. Thus, the local authorities mobilised to remove the settlers as fast as possible, and the NHA provided this opportunity. In this way, the original lobbying statements of the civil society, which helped it to secure the P50 billion fund, were positioned against the People's Plans approach.

Admittedly, these plans were not present and the model of development was uncertain in the early stage of the programme, since: "there is a lot of money, you have DILG, NHA, SHFC so you do not know who really is the main agency who coordinate who assist, who evaluates, how this fund was being used and utilised" (People's Organisation, 07-12-2017). Most of the informal communities lacked strong organisation and agency to engage with it, which meant "they are left at the mercy of 
default option, which is off-city resettlement" (public sector/civil society 02.03.2018). Consequently, there were reports of communities mobilised to engage in the People's Planning process shifting position and opting for the cheaper and more rapid off-city solution proposed by the NHA. However, although the approach had the true advantage of being fast and inexpensive for the beneficiaries, the aforementioned socio-political factors can be considered as equal, if not more important, to the way the P50 billion fund was utilised. These factors emerge as central points of debate when considering the quality of the delivered sites and the socio-economic effects of off-city resettlement (as illustrated by an evaluation of the long-term benefits of in-city relocation compared to the off-city standardised approach) (Ballesteros and Egana, 2012). As expected, the off-city resettlement sites built within Oplan LIKAS experienced the same issues as the resettlements constructed in previous decades. Some of the relocation sites lacked adequate water and electricity services, and the livelihood restoration support in these sites was limited (World Bank, 2017). Owing to these issues, the government committed to providing additional investment and upgrading interventions. In 2017, about P1.8 billion, taken from the newly reserved P5.5 billion, was released for improvements works in these neighbourhoods (Bonaqua, 2017).

\section{Control Over Resources and Development, Institutionalisation and the Land}

\section{Access Issue}

Having established the socio-political context of off-city relocation, I discuss here the resistance of the political and bureaucratic machinery within the conservative strain of the key shelter agencies as the opposition to two key objectives of the civil society: gaining wider access to resources and greater control over the development process, as laid out in section 3 of this article.

The difficulty of attaining a balanced influence on governance is clearly exhibited in the land access issue. This central determinant for the success of any resettlement programme was problematic in the Metro Manila context during the decades preceding the programme. In the early post-colonial period, private sector actors belonging to several powerful families, such as the Ayalas, Aranetas, Ortigases and Tuazons, dominated the local real estate market (Garrido, 2013). In the following decades, the urban enclaves, ranging from gated communities to condominium districts, which were 
developed by financially capable private investors, occupied more and more land with exclusive designation for local elites, expats and overseas Filipino workers (Kleibert, 2018). This stark competition for land positioned informal settlers as the key, yet easily removable, 'obstacle' for the reinvention of commercially valuable areas in Metro Manila (Choi, 2016). According to the law, the local government units (LGUs) are mandated to delimit land for social housing within their boundaries. However, by the end of the Oplan LIKAS process, only 5 out of the 16 cites and one municipality in Metro Manila updated the Comprehensive Land Use Plans in place (World Bank, 2017), which meant insufficient or no land reserved for social housing. The situation was not challenged even with the support of international agencies such as the Asian Development Bank, which unsuccessfully promoted land sharing and subsidiary models for in-city social housing in the years preceding the Oplan LIKAS (Hutchison, Hout, Hughes \& Robison 2014). These issues, including "problems on determining vacant land for in-city relocation" (key shelter agency, 01.02.2018) provided the NHA with a justification for their focus on off-city relocation when faced with the lack of lands reserved for social housing by the LGUs.

However, the civil society designed a mechanism to address the problem. Facing difficulties in obtaining land, the leaders of the main urban poor groups agreed on a multi-storey housing approach (World Bank, 2016), which in previous decades had been contested in the low-income communities (Karaos, 2006). The principles of the People's Plans were embedded in the High Density Housing programme of the SHFC (Figure 1). The communities were entitled to find their own land, select developers for the construction, manage the process and establish facility management structures. Thus, the institutionalisation of the land research component was supposed to counterbalance the inability (or unwillingness) of the local governments to fulfil their statutory function and to support in-city relocation. As such, the communities were to retain greater control over the development process through land identification while being entitled to source resources from the P50 billion fund to develop their multistorey housing. This type of compromise had mixed results. Given the small number of projects completed with the People's Plans (Table 1) by the end of 2017, the process turned out to be vulnerable to various challenges. In addition to the issue of community mobilisation, the land access issue was again what the civil society leaders identified as critical. As noted by one of the civil society leaders: "It should have been in-city because 
we don't believe in off-site so they allocated 50 billion but this is not enough because money alone (...) and People's Plans will be not a guarantee if you have no land" (civil society, 08-12-2017b). For instance, the CSO representatives reported that the land identified by the communities, after a tedious and lengthy process, was in some cases immediately purchased by a LGU once the community 'revealed' its information. Similar difficulties were reported in the search for public land by some communities, with the public sector characterised by a tendency to resist or delay the process, while "there is too much trouble we encounter in raising the fund, explaining the technicalities and about the conflict of legalities, conflict of mandate" (People's Organisation, 10-03-2018).

In effect, these challenges relate to the question of whether the co-productive engagement of the civil society can indeed ensure a tighter degree of control over the development process while simultaneously helping the process of the redistribution of resources.. The main stumbling block for using the fund for in-city relocation was the lack of land access. Civil society operations did unblock some of the idle lands in the metropolis for mid-rise buildings. However, these small successes did not translate into a general shift towards land accessibility. Thus, the institutionalisation of land research by communities could be positioned as an ersatz solution to a bigger problem, which lies in the blockage of public and private land for different priorities. This issue may be linked to simple economic gain or the aforementioned orientation of formal planning towards the needs of elite consumers (Garrido, 2013). In the absence of a fixed legal basis on a countrywide scale making in-city relocation (or the near-city option) mandatory and requiring that resettlement be generally driven by People's Plans, programme-level institutionalisation was easily condemned by its critics as a slow and expensive solution. This response questions the extent to which institutionalised coproduction (Joshie \& Moore, 2004) can affect broader governance trends. The case study suggests that in an exclusionary governance setting, two out of the three levels of institutionalisation discussed by Ackerman (2004), namely, inscribing a participatory mechanism into the strategic plans of the government and setting up new agencies ensuring participation, may be easily contested. The third level, inscribing the participatory solution into law, was acknowledged by some of the civil society groups as a missing element in the Oplan LIKAS process. Currently, based on the efforts of CSOs and urban poor groups, the bill on "on-site, in-city or near-city" resettlement in support of People's Plans is pending in the Philippine Senate. However, when tracing the 
implementation of UDHA legislation from 1992, including the previously discussed failure to identify the land for social housing purposes, the effects of the third level of institutionalisation remain unknown.

\section{Co-production in Perspective}

The process of the formation of the UP-ALL, the 10-point covenant and the establishment of the P50 billion fund for the ISFs is an example of the civil society and urban poor sector achieving movement from small and mezzo-scale co-productive projects to the metro-scale engagement of co-production of urban space and governance in Metro Manila. However, the implementation of the programme also illustrates how volatile this achievement was. The analysis suggests that the strategies leading to the success of CSOs in the scaling-up phase were less successful in the governance/implementation phase.

The success achieved in the first phase lies in three key points. Firstly, the initial phase included the internal ability to build up a network large enough to engage in collective action. Secondly, it involved external boosting of the credibility of the alliance through multiple engagements at different levels of governance, starting at community level and ending in cooperation with international agencies (Herrle et al., 2015). Socialmovement initiated co-production, understood as a deliberate mobilisation and engagement in the service delivery process, was instrumental in these two points. However, the third crucial point, the importance of the contestation and advocacy strategies utilised by a part of the UP-ALL network, questions the understanding of coproduction as a consensual engagement and points out how it differs from the collaborative planning process (Watson, 2014). In fact, collaboration, contention and subversion are identified as complementary strategies of the grassroots (Mitlin, 2018). The research supports the view that the interaction of co-production and non-violent protest activities, including court action, are so strongly intertwined and built upon each other that they form a part of one approach. The network did, in principle, aim at non-violent forms of contention whenever the power 'generated,' though co-productive engagements did not enable them to secure their interests. For instance, in the context of Montinlupa City, where competition for land was relatively limited and the local government was open to cooperation with communities, the mapping activities of the 
HPFPH could be scaled up without the need to resort to more confrontational measures. In Manila, where local government is much less open to cooperation and where competition for land is extreme, rallies in support of co-production and against relocation emerge as an essential part of the strategy. Similarly, at project level, resisting relocation was in some cases a starting point for utilising elements of coproduction and the People's Plans.

This approach may resonate also in the activities of the international networks, commonly labelled as utilising co-production, including the SDI, which, in spite of its declared separation from contention strategies, has regional affiliates who integrate it into their actions (Huchzermayer, in press). In other words, the research confirms that the ideal model of conflict-free co-production, either at community level or on the community-politics interface, is highly unlikely, particularly when we talk about coproduction of governance. Finally, even if these activities of the co-production-oriented urban poor bloc were not characterised by clearly confrontational dynamics typical of political movements aiming at universal transformation (Dikeç \& Swyngedouw, 2017), the pre-electoral street-level activities of the UP-ALL were a form of political act. In fact, simply building up a network through the co-productive process is, in itself, political. Forming a massive grouping capable of affecting political processes makes these groups and their leaders a relevant force in election-based systems. As such, the ability to form ad hoc alliances (starting from the bottom-up level within small administrative units) should be brought into the debate as an important element framing the co-productive arrangements.

Using these three key approaches, the civil society achieved the following in the first phase:

- secured a redistribution of resources for social housing,

- positioned its main agenda points at the centre of planning discussions and

- had their representatives taken on by some of the most important shelter agencies in Metro Manila.

These achievements left several tangible legacies, such as proving that in-city resettlement and multi-storey social housing is an option, building a direct engagement between urban poor groups and the private sector and designating the People's Plans as an approach for planned resettlement projects in the country (mentioned in the documentation concerning the North-South Rail project). However, the implementation 
of the programme remains in sharp contrast to the hopes that were awakened by the P50 billion fund. It was already clear during the implementation phase of the Oplan LIKAS that the three aforementioned achievements were being challenged. The reasons for this contestation lay beyond the practicalities of the approach, such as cost of an intervention or its applicability to the needs of the concerned communities.

The bureaucratic and political machinery severely contested the civil society approaches, and was effective in doing so because of off-stage lobbying and the shaping of the programme in accordance with conventional budgetary and implementation measures. On the one hand, the urban poor groups, which were effective in navigating informality in their own context, had fewer tools to engage with the informality unfolding in the bureaucratic environment of the key shelter agencies. On the other hand, attempts to integrate the approaches of the civil society were also contested by the 'formal' and operational logic of bureaucracy in Metro Manila and the institutional setup it promoted. In this context, the NHA planning routine was put forward as a justification for continuing to deliver services in the same way as it had always done, failing to recognise that off-city resettlement planning, with its territorial and procedural dimensions, was a form of control and oppression (Yiftachel, 1998). Similarly, as in the international context, this happened despite the supposed openness of the power holders and policy logic, which operated with the language of inclusiveness (Appadurai, 2001; Watson, 2011) but pushed for the P50 billion fund to be allocated to conventional housing modality. While the People's Plans were supposed to be guaranteed through a set of important documents, such as the Joint Memorandum Circular, the flexibility of the approach contradicted the rigid process of the yearly disbursement of money and the legal mandate of the LGUs to vacate in a timely manner, the risk-prone areas around waterways. Thus, the involvement of civil society actors in the process exposed them to the political and intra-bureaucratic dynamics they encountered on a smaller scale when acting as an extraneous power attempting to be involved in governance. The contestation strategies, which were relevant during the scaling up phase, were arguably less effective because the civil society representatives managed the implementation process and were somehow subjected to the logic of 'accomplishing the project'. Additionally, the programme was hampered by the land access issue. The institutionalisation of the People's Plans revealed itself as a doubleedged sword: the discourse on the speed of the classical off-city resettlement was 
positioned against the 'slowness' of the people's solutions. When local governments and governmental agencies compete for the same resource as the civil society, coproduction is at risk of being contested. In this context, the institutionalisation of land research by the communities, within the High Density Housing programme, may not be enough to overcome the passivity of the LGUs in the execution of their legal function, namely securing in-city land for social housing. This point confirms that the institutionalisation of co-production in the context of the South is not uniformly a guarantee that the urban poor will succeed in mainstreaming their approaches, particularly when the implementation logic of a programme counters the spirit of those approaches, or when it is used as an ersatz justification for the negligent execution of pro-poor law.

What the above-mentioned experiences mean for the understanding of the coproduction governance change process, is that innovations achieved at project- or mezzo-level will typically be challenged when scaling up. The main challenges are linked to the aspiration of mirroring own protocols and ensuring flexibility within coproduced governance when organisations have to operate within existing legal systems which run counter to those principles. While co-production is conventionally a way of overcoming the shortcomings of official regulations (Watson, 2014) and tends to work when there is a strong relationship between the local authorities and the communities, the aspiration to scale up exposes these innovations to a conventional bureaucratic machinery typically more interested in quantitative success than qualitative improvements (Galuszka, 2017). In such cases, the conventional wisdom that comanagement and co-governance are enabled by institutionalisation and the public sector should be questioned in the context of exclusionary governance settings. The failure of civil society to fully benefit from the context created by the Oplan LIKAS suggests that co-production of governance is an open-ended process which will experience highs and lows while interacting with the bureaucratic machinery of the state. Maintaining a mobilised network of people engaged in collective action and, even unintentionally, representing some sort of unaffiliated political power able to negotiate ad hoc coalitions, might be a stronger guarantee of sustainability of People's approaches than the creation of programme-level frameworks (which may or may not be helpful depending on the wider governance context). This points to the centrality of the 
internal function of co-production, namely its role in creating large networks linked through collective action.

However this 'security buffer' for co-production of governance - the active, interlinked and numerous community-organisations - may paradoxically be threatened when the changes instigated by social movements take the form of resources. The mobilisation of the communities on the ground within the Oplan LIKAS was not as smooth as expected, and this resulted in a large number of people opting for resettlement in off-city neighbourhoods. As much as this can be attributed to the active lobbying of conservative actors, it also suggests that co-productive modality, such as High Density Housing, may not be uniformly attractive to informal dwellers when its initial costs outweigh long-term benefits (Ballesteros, Ramos \& Magtibay, 2017). This points to the issue of representation within the co-productive process and poses the following question: Are people willing to engage in co-production when given direct access to resources, even if these resources are in faraway relocation sites? Similar to the experiences of the Capital Subsidy Scheme in South Africa, the ease of pushing people to these off-city sites without serious contestation (World Bank, 2017) suggests that the resources may function as an instrument of socio-economic control, in which "popular awareness of this individual entitlement leads directly to a demand for standardized delivery, leaving no space for collective reflection on the appropriateness of the individualized product" (Huchzermeyer, 2003, p. 600). Although in the Philippine context 'entitlement' is only partial since the housing must be paid for, a similar role is likely played by the lower cost of an off-city location which comes with a clear ownership title, compared to the usufruct agreement that applies in most in-city locations. Consequently, the sustainability of the P50 billion fund was hampered by the civil society's lack of control over the distribution of the money, suggesting that neither of their goals - redistribution of resources and control over the process - was totally achieved.

\section{Conclusions}

This article documents the engagement of the civil society in urban governance in Metro Manila beyond the process of small and mezzo-scale cooperation projects with the public sector. The scaling up phase was linked to the considerable success of the UP- 
ALL, manifested by the establishment of the P50 billion fund, the orientating policy discussion on the issues of co-productive modality of People's Plans and in-city resettlement, and the employment of civil society actors in the main implementing agencies of the Oplan LIKAS programme. As such, the engagement achieved much more than past participatory approaches, which provided some new communication channels between the society and the state but failed to impact directly on policy making (Karaos, 2006) or help to disentangle communities from the patronage of powerful figures (Hutchison, 2007; Porio, 2012). However, the governance/implementation phase revealed that these achievements left a few tangible legacies, among them proof that a people-driven development of in-city, mid-rise social housing is possible. The fund was mainly utilised for conventional off-city resettlement, People's Plans were rarely developed, and a majority of the civil society activists lost their jobs in the key shelter agencies after the change of political leadership in the country.

An analysis of the process offers several valuable lessons for understanding and advancing a governance-oriented co-productive process in an exclusionary governance setting.

Firstly, the centrality of conflict in the process remains crucial. The cooperative dimensions of co-production are essential in the scaling up phase - and have both an internal function (to build up a network) and an external function (to build relationships with government). As a result of these two functions the co-production movement reaches further than participatory schemes, which may dismantle collective agenda-building and promote existing solutions rather than devising new ones. However, moving into co-production of governance is unlikely to happen unless the movement, or a part of it, is able to engage in protests, manifest dissatisfaction, resist relocation, establish interactions with high-level politicians and, in so doing, be perceived as possessing political power. Therefore, the conventional understanding of entirely non-political, consensual movements focusing on co-production is put into question when groups try to scale up and genuinely affect urban governance, especially in an exclusionary setting. I argue here that at this stage co-production of governance requires the integration of protest-based strategies, and that consensus- and contention-based approaches are barely separable. Purely consensual co-production that mainly employs a showing-by-doing approach may be effective in an inclusive 
setting, but this is unlikely to be the case in contexts where land prices are skyrocketing.

Secondly, the research questions the assumption that institutionalised coproduction (Joshi and Moore, 2004) is a guarantee of the sustainability of the approach. If the co-productive approach is institutionalised at project and programme level without broader support at governance level, then the process itself may limit the reach of the approach and exhibit the same vulnerabilities as participatory planning schemes. Such a mechanism may actually result in the positioning of co-productive solutions as 'innovations' or as 'alternative' service delivery mechanisms, with the majority of public contracts being consumed by big developers offering standardised mass housing in peripheral locations of cities. This relates to the notion of conflicting rationalities (Watson, 2003) and powerful imaginaries of a dichotomy between formal and informal sectors (McFarlane, 2012b) as strong drivers motivating replication of 'formal' urban practice.

Thirdly, even if communities engage in collective action and are the proponents of governance change, their outputs, such as redistribution of resources, may, in fact, hamper mainstreaming of co-production. In other words, the assumption that communities will always be eager to lead the process of change may be valid when they do not have any other solutions to hand. Yet, when offered faster, ready-made alternatives while being pressured to relocate, many people will choose these over a complex co-productive process, especially when community leadership is weak or fragmented. This also means that reflection on intra-community relations as a precondition for the leveraging of co-production should be repositioned at the centre of the academic inquiry.

Overall, co-production remains a highly paradoxical process. It does instigate change of governance but at the same time its intrinsic vulnerabilities may affect the sustainability of the change. Addressing this paradox is central for academicians and for the civil society actors themselves in order to make progress in scaling up the approach and developing more equitable urban settlements and governance systems. While coproduction may be one of the most powerful mechanisms for citizens to meaningfully engage with the public sector, when the engagement reaches the highest level of governance it will experience strong resistance of conservative actors. What it reveals about governance structures in an exclusionary context is that rigid regulatory 
mechanisms can be used to support a wholly informal set of dependencies and pressure mechanisms reinforcing the interests of power holders. The sustainability of people's solutions may truly depend on the ability to navigate those spaces. Consequently, the way forward in understanding the governance change process in an exclusionary governance setting requires the adaptation of renewed analytical frameworks. Such frameworks should question the theoretical underpinnings of this process, based on assumptions largely deriving from 'developed' contexts (Yiftachel, 2006; Roy, 2009b). The juxtaposition of institutionalisation vs. flexibility, conflict vs. cooperation, and control over the development process vs. redistribution of resources, may offer a useful analytical device for the analysis of such a process and for reaching a deeper understanding of the complexities of the governance transformation in the South.

\section{Acknowledgments:}

I would like to thank Dr Marife Ballesteros and the Philippine Institute for Development Studies for the support in the realisation of the research as well as all of the interviewees who contributed with their knowledge and time.

\section{Funding:}

The publication of the article was supported by the DAAD/BMZ.

\section{Bio:}

Jakub Galuszka is an urban planner and sociologist currently working as a researcher at the Habitat Unit, Technical University of Berlin. Before joining the Habitat Unit he worked and conducted research in Poland, the Philippines, Georgia and South Africa.

\section{References}

Ackerman, J. (2004). Co-governance for accountability: beyond "exit" and "voice". World Development, 32(3), 447-463.

Ackerman, J. (2012). From co-production to co-governance. In V. Pestoff, T. Brandsen, \& B. Verschuere (Eds.), New Public Governance, The Third Sector, and Co-production (pp. 119-144). New York/London: Routledge.

Akaateba, M. A., Huang, H., \& Adumpo, E. A. (2018). Between co-production and institutional hybridity in land delivery: Insights from local planning practice in peri- 
urban Tamale, Ghana. Land Use Policy, 72, 215-226.

Albrechts, L. (2013). Reframing strategic spatial planning by using a coproduction perspective. Planning Theory, 12(1), 46-63.

Appadurai, A. (2001). Deep democracy: urban governmentality and the horizon of politics. Environment and Urbanization, 13(2), 23-43.

Archer, D. (2012). Finance as the key to unlocking community potential: savings, funds and the ACCA programme. Environment and Urbanization, 24(2), 423-440.

Ballesteros, M.M. (2002). Rethinking institutional reforms in the Philippine housing sector. PIDS Discussion Paper Series, No. 2002-16. Makati City: Philippine Institute for Development Studies (PIDS).

Ballesteros, M.M \& Egana J. (2012). Efficiency and effectiveness review of the National Housing Authority (NHA) Resettlement Program. Philippines Institute for Development Studies/Department of Budget and Management.

Ballesteros M.M, Ramos T.P \& Magtibay J.E. (2017). An assessment of the Community Mortgage Program implementation strategy. Research Paper Series 2017-01, Philippine Institute for Development Studies.

Banks, N., Hulme, D., \& Edwards, M. (2015). NGOs, states, and donors revisited: Still too close for comfort?. World Development, 66, 707-718.

Bonaqua, K. (2017, May 13). A people's plan to house the poor. Philippine Daily Inquirer. Retrieved from http://opinion.inquirer.net/

Boonyabancha, S., \& Kerr, T. (2018). Lessons from CODI on co-production. Environment and Urbanization, 30(2), 444-460.

Bovaird, T. (2007). Beyond engagement and participation: User and community coproduction of public services. Public Administration Review 67(5): 846-860. Bradlow, B. H. (2015a). City learning from below: urban poor federations and knowledge generation through transnational, horizontal exchange. International Development Planning Review, 37(2), 129-142.

Bradlow, B. H. (2015b). Quiet conflict: institutional change, informal settlement upgrading, and formalized partnerships between local authorities and urban social movements in South Africa. In P. Herrle, A. Ley \& J. Fokdal (Eds.), From local action to global networks: Housing the urban poor (pp. 101-120). London: Ashgate Publications. Brandsen, T., \& Pestoff, V. (2006). Co-production, the third sector and the delivery of public services: An introduction. Public management review, 8(4), 493-501. 
Brandsen, T., \& Honingh, M. (2016). Distinguishing different types of coproduction: A conceptual analysis based on the classical definitions. Public Administration Review, 76(3), 427-435.

Brown-Luthango, M., \& Reyes, E. (2018). Urban upgrading to reduce violence in informal settlements. In G. Bhan, S. Srnivas, \& V. Watson (Eds.), The Routledge Companion to Planning in the Global South (pp. 298-309). New York: Rutledge.

Castells, M. (1983). The city and the grassroots: a cross-cultural theory of urban social movements. Berkeley: University of California Press.

Cepiku, D., \& Giordano, F. (2014). Co-production in developing countries: Insights from the community health workers experience. Public Management Review, 16(3), 317-340. Chitekwe-Biti, B. (2018). Co-producing Windhoek: the contribution of the Shack Dwellers Federation of Namibia. Environment and Urbanization, 30(2), 387-406.

Choi, N. (2016). Metro Manila through the gentrification lens: Disparities in urban planning and displacement risks. Urban Studies, 53(3), 577-592.

Brown-Luthango, M., \& Reyes, E. (2018). Urban upgrading to reduce violence in informal settlements. In G. Bhan, S. Srnivas, \& V. Watson (Eds.), The Routledge Companion to Planning in the Global South (pp. 298-309). New York: Rutledge. Castells, M. (1983). The city and the grassroots: a cross-cultural theory of urban social movements. Berkeley: University of California Press.

Cepiku, D., \& Giordano, F. (2014). Co-production in developing countries: Insights from the community health workers experience. Public Management Review, 16(3), 317-340. Chitekwe-Biti, B. (2018). Co-producing Windhoek: the contribution of the Shack Dwellers Federation of Namibia. Environment and Urbanization, 30(2), 387-406.

Choi, N. (2016). Metro Manila through the gentrification lens: Disparities in urban planning and displacement risks. Urban Studies, 53(3), 577-592.

Constantino-David, K. (2004). Unsustainable development: the Philippine experience. In Westendorff, D. From Unsustainable to Inclusive Cities. Geneva: UNRISD.

Cooke, B. \& Kothari, U. (2001). Participation: the new tyranny? London: Zed Books. Cornwall, A. (2004). Introduction: New democratic spaces? The politics and dynamics of institutionalised participation. IDS bulletin, 35(2), 1-10.

DILG (Department of Interior and Local Government). (2017). Accomplishment report January - December 2017. Unpublished Manuscript, DILG. 
DILG (Department of Interior and Local Government). (2018). Resettlement governance. Power Point presentation. Unpublished Manuscript, DILG.

Dikeç, M., \& Swyngedouw, E. (2017). Theorizing the politicizing city. International Journal of Urban and Regional Research, 41(1), 1-18.

Environment \& Urbanization. (2018). 30(2), 355-633.

Frantzeskaki, N., \& Rok, A. (2018). Co-producing urban sustainability transitions knowledge with community, policy and science. Environmental Innovation and Societal Transitions, 29, 47-51.

Galuszka, J. (2014). Community-based approaches to settlement upgrading as manifested through the big ACCA projects in Metro Manila, Philippines. Environment and Urbanization, 26(1), 276-296.

Galuszka J. (2017). Evidence-based planning and housing approaches bias: methodological alternatives for broadening policy options in mass housing programs. In: Urban Perspectives: Climate Change, Migration, Planning - A New Generation of Ideas 2017 (pp. 64-85). Washington, DC: Wilson Center.

Galuszka, J. (2019). What makes urban governance co-productive? Contradictions in the current debate on co-production. Planning Theory, 18(1), 143-160.

Garrido, M. (2013). The ideology of the dual city: The modernist ethic in the corporate development of Makati City, Metro Manila. International Journal of Urban and Regional Research, 37(1), 165-185.

Garrido, M. (2017). Why the poor support populism: the politics of sincerity in Metro Manila. American Journal of Sociology, 123(3), 647-685.

Gerald N. (2011, December 6). The price of informed advocacy: UP-ALL's experience in negotiating housing solutions. Retrieved from https://www.philssa.org.ph/

Habito, C.F. (2009). Patterns of inclusive growth in developing Asia: insights from an enhanced growth-poverty elasticity analysis. ADBI Working Paper 145. Tokyo: Asian Development Bank Institute.

Herrle, P., Ley A., \& Fokdal J. (Eds.). (2015). From local action to global networks: housing the urban poor. London: Ashgate Publications.

Huchzermeyer, M. (2003). A legacy of control? The capital subsidy for housing, and informal settlement intervention in South Africa. International Journal of Urban and Regional Research, 27(3), 591-612.

Huchzermayer, M. (forthcoming). Informal settlement representation through 
Slum/Shack Dwellers International (SDI). In A. Mayne (Ed.) Oxford University Press Handbook of Modern History of Slums. Oxford: Oxford University Press.

HUDCC (Housing and Urban Development Coordination Council). (2010, August 16). VP

Binay to NHA: Review resettlement policies. Retrieved from http://www.hudcc.gov.ph/pr081610

HUDCC (Housing and Urban Development Coordination Council). (2017). Balai Filipino: Housing Beyond 2022. Unpublished Manuscript.

Hutchison, J. (2007). The 'disallowed' political participation of Manila's urban poor. Democratization, 14(5), 853-872.

Hutchison, J., Hout, W., Hughes, C., \& Robison, R. (2014). Political economy and the aid industry in Asia. London: Palgrave Macmillan.

Jasanoff, S. (Ed.). (2004). States of knowledge: the co-production of science and the social order. London/New York: Routledge.

Joshi, A., \& Moore, M. (2004). Institutionalised co-production: unorthodox public service delivery in challenging environments. Journal of Development Studies, 40(4), 31-49.

Karaos, A.M. (2006). Populist mobilization and Manila's urban poor: the case of SANAPA in the NGC East Side. In A. Fabros, J. Rocamora \& D. Velasco (Eds.), Social movements: experiences from the Philippines (pp. 46-102). Quezon City: Institute for Popular Democracy.

Karaos, A.M., \& Porio E. (2015). Transforming the housing process in the Philippines: The role of local-global networks by the urban poor. In P. Herrle, A. Ley and J. Fokdal (Eds.), From local action to global networks: Housing the urban poor (pp. 107-121). London: Ashgate Publications.

Kleibert, J. M. (2018). Exclusive Development (s): Special Economic Zones and Enclave Urbanism in the Philippines. Critical Sociology, 44(3), 471-485.

Lefèvre, H. (1974) La production de l'espace. Paris: Anthropos.

Lemanski, C. (2017). Unequal citizenship in unequal cities: participatory urban governance in contemporary South Africa. International Development Planning Review, 39(1), 15-35.

Mabilin, M. (2014). Forced-evictions, off-city relocation and resistance: Ramifications of neo-liberal polices towards the Philippines urban poor. In: H. Moksens and M. Melin (Eds.), Claiming the civil society mobilisation by the urban poor (pp. 133-138). Uppsala: Uppsala Centre for Sustainable Development. 
McFarlane, C. (2012a). The entrepreneurial slum: Civil society, mobility and the coproduction of urban development. Urban Studies, 49(13), 2795-2816.

McFarlane, C. (2012b). Rethinking informality: Politics, crisis, and the city. Planning Theory \& Practice, 13(1), 89-108.

Miraftab, F. (2004). Neoliberalism and casualization of public sector services: the case of waste collection services in Cape Town, South Africa. International Journal of Urban and Regional Research, 28(4), 874-892.

Miraftab, F. (2009). Insurgent planning: Situating radical planning in the global south. Planning Theory, 8(1), 32-50.

Mitlin, D. (2008). With and beyond the state-co-production as a route to political influence, power and transformation for grassroots organizations. Environment and Urbanization, 20(2), 339-360.

Mitlin, D. (2018). Beyond contention: urban social movements and their multiple approaches to secure transformation. Environment and Urbanization, 30(2), 557-574.

Mitlin, D., \& Bartlett, S. (2018). Co-production-key ideas. Environment and Urbanization, 30(2), 355-366.

Mitlin, D., \& Satterthwaite, D. (2004). The role of local and extra-local organizations. In D. Mitlin, \& D. Satterthwaite (Eds.) Empowering squatter citizen: Local government, civil society and urban poverty reduction pp. 278-306. London/Sterling, VA: Erthscan.

Moretto, L., Faldi, G., Ranzato, M., Rosati, F. N., Ilito Boozi, J. P., \& Teller, J. (2018). Challenges of water and sanitation service co-production in the global South. Environment and Urbanization, 30(2), 425-443.

Ostrom, E. (1996). Crossing the great divide: coproduction, synergy, and development. World development, 24(6), 1073-1087.

Papeleras, R., Bagotlo, O., \& Boonyabancha, S. (2012). A conversation about changemaking by communities: some experiences from ACCA. Environment and Urbanization, 24(2), 463-480.

Patel, K. (2013). A successful slum upgrade in Durban: A case of formal change and informal continuity. Habitat International, 40, 211-217.

Patel, S., Baptist, C., \& d'Cruz, C. (2012). Knowledge is power-informal communities assert their right to the city through SDI and community-led enumerations. Environment and Urbanization, 24(1), 13-26.

Patiño, P.I. (2016). Building resilient and safe communities against poverty and disaster. 
Asian Cities Climate Resilience (Working Paper Series 29). International Institute for Environment and Development.

Pieterse E. (2008). City futures: confronting the crisis of urban development. London; New York: Zed Books.

Porio, E. (2012). Decentralisation, power and networked governance practices in Metro Manila. Space and Polity, 16(1), 7-27.

Porio, E., \& Crisol, C. (2004). Property rights, security of tenure and the urban poor in Metro Manila. Habitat International, 28(2), 203-219.

Richardson, L., Durose, C., \& Perry, B. (2018). Coproducing urban governance. Politics and Governance, 6(1), 145-149.

Rigon, A. (2014). Building local governance: Participation and elite capture in slumupgrading in Kenya. Development and Change, 45(2), 257-283.

Roy, A. (2009a). Civic governmentality: The politics of inclusion in Beirut and Mumbai. Antipode, 41(1), 159-179.

Roy, A. (2009b). The 21st-century metropolis: new geographies of theory. Regional Studies 43.6, 819-830.

Sarmiento, H., \& Tilly, C. (2018). Governance lessons from urban informality. Politics and Governance, 6(1), 199-202.

Shatkin, G. (2002). Working with the community: Dilemmas in radical planning in Metro Manila, the Philippines. Planning Theory \& Practice, 3(3), 301-317.

Shatkin, G. (2007). Collective action and urban poverty alleviation: Community organizations and the struggle for shelter in Manila. Hampshire: Ashgate Publishing.

Swyngedouw, E. (2005). Governance innovation and the citizen: the Janus face of governance-beyond-the-state. Urban Studies, 42(11), 1991-2006.

UDHA. (1992, March 24). Republic act no. 7279 "Urban Development and Housing Act of 1992".

Retrieved

from

http://www.chanrobles.com/republicactno7279.htm\#.WogDL2MvggI

Voorberg, W. H., Bekkers, V. J., \& Tummers, L. G. (2015). A systematic review of cocreation and co-production: Embarking on the social innovation journey. Public Management Review, 17(9), 1333-1357.

Watson, V. (2003). Conflicting rationalities: implications for planning theory and ethics. Planning Theory \& Practice, 4(4), 395-407. 
Watson, V. (2011). Changing planning law in Africa: An introduction to the issue. Urban Forum, 22(3), 203-208.

Watson, V. (2014). Co-production and collaboration in planning - the difference. Planning Theory \& Practice, 15(1), 62-76.

Whitaker, G. P. (1980). Coproduction: Citizen participation in service delivery. Public administration review, 40(3), 240-246.

World Bank. (2016). Republic of the Philippines Housing and Urban Development Summit. Closing the gap in affordable housing in the Philippines: policy paper for the National Summit on Housing and Urban Development. Manila: World Bank.

World Bank. (2017, September 1). Project appraisal document on a proposed loan in the Amount of US\$207,60 million to the Republic of Philippines for a Metro Manila Flood Management Project. Retrieved from

http://documents.worldbank.org/curated/en/192891506823261036/pdf/PHILIPPINE S-PAD-09082017.pdf

Wyborn, C. (2015). Co-productive governance: a relational framework for adaptive governance. Global Environmental Change, 30, 56-67.

Yiftachel, O. (1998). Planning and social control: Exploring the dark side. Journal of planning literature, 12(4), 395-406.

Yiftachel, O. (2006). Essay: re-engaging planning theory? Towards 'South-Eastern' perspectives. Planning Theory 5(3), 211-222.

Yu, S., \& Karaos, A. M. (2004). Establishing the role of communities in governance: the experience of the Homeless People's Federation Philippines. Environment and Urbanization, 16(1), 107-120. 